\title{
Insects pests
}

\author{
Carlos Henrique Marchiori $^{1}$ \\ 1 Ins tituto Federal Goiano
}

Insects pests

Insects and humans cohabit the Earth and have developed complex relationships. Insect pests (less than $1 \%$ of all species) are those insects that feed on, compete for food with, or transmit diseases to humans and livestock. The female mosquito pierces her victim's skin with its long, slender proboscis, sucking out up to three times her body weight in blood (Sovak, 1989).

\section{Mosquito}

Insects and humans cohabit the Earth and have developed complex

relationships. Insect pests (less than $1 \%$ of all species) are those insects that feed on, compete for food with, or transmit diseases to humans and livestock. Ecosystems modified by human activities have provided opportunities for insects, and species that successfully adapt often become pests (Borror, et al., 1981)

\section{Effects on Humans}

The human body provides food and shelter for the crab louse and 2 forms of human louse (head and pubic lice). Fleas and bedbugs obtain food from human bodies and inhabit human dwellings between blood meals. Out of doors, humans are attacked by blood-sucking flies (mosquitoes, black flies, horse and stable flies), which torment victims and may cause toxic or allergic reactions. In Canada, human dwellings, barns and other buildings are essential for the survival of insects from warmer climes (eg, cockroaches, clothes moths, carpet beetles, silverfish and some species of ants). (Borror, et al., 1981). Many blood-sucking insects are vectors of human diseases, picking up the disease organism while feeding on an infected host (human or animal) and infecting subsequent victims. Human lice are important vectors of trench fever, relapsing fever and epidemic typhus; fleas can transmit plague bacilli from rodents to humans; and different species of mosquitoes transmit malaria and encephalitis. In these diseases, the insect is an essential part of the chain of development of the disease organism, but other diseases are transmitted mechanically. The house fly, which occurs almost worldwide, breeds on 
organic wastes and can carry disease organisms to food (T urnock, 2012).

\section{Attacks on Livestock}

Livestock are attacked by the same types of insects as humans. Each type of livestock is attacked by one or more species of lice, which causes lack of vigour and stunted growth. Blood-sucking flies (eg, face, horn and the introduced stable fly) feed on and pester cattle, reducing growth and milk production. In some areas, mosquitoes or black flies may be so abundant that they reduce cattle feeding and may cause stampedes. Native black flies can cause severe anemia and even death. Cattle raised in black fly areas are somewhat resistant to attack, but animals brought in for herd improvement lack resistance and suffer severely or die (https://www.thecanadianencyclopedia.ca/en/article/insect-pests).

\section{Effects on Plants}

In Canada, short growing seasons and cold winters restrict most insects to one generation annually. This reduces the number of pest species and the amount of damage they cause, in comparison with the impact of pest species in warmer parts of the world. Nevertheless, insects cause significant losses, and their control adds to the cost of many agricultural and forestry products (T urnock, 2012).

\section{Cultivated Crops}

Intensive agriculture encourages the development of insect pests by concentrating food items (crop plants and stored food) on which insects can feed. Food-plant concentrations, often in monoculture, also may reduce the effectiveness of natural enemies attacking pest species in natural environments. Insects may attack any part of the plant, at any stage of development (https://www.thecanadianencyclopedia.ca/en/article/insect-pests).

Seed grains and potatoes are attacked by wireworms; newly germinated seedlings of almost all crops are attacked by cutworms, while flea beetles are a major pest of newly germinated canola and other cruciferous crops; growing plants are fed on by climbing cutworms, armyworms, aphids, Colorado potato beetles, etc; corn ears are fed on by corn borers and grain ears by several species of aphids. Several species of beetles and moths may infest stored grain, and other species of these groups feed on flour and processed foods (https://www.thecanadianencyclopedia.ca/en/article/insect-pests). 
information on this subject is available. Yield losses of up to 5\% per year and a maximum of $25 \%$ are estimated for cereal grains and of 5-10\% for canola, despite expenditures for pesticides. The average yield loss is only $3 \%$ of onion, apple and potato crops, but these losses would be $30-70 \%$ on onions, $50-100 \%$ on apples and and $30-50 \%$ on potatoes if insecticides were not used (https://www.thecanadianencyclopedia.ca/en/article/insectpests).

\section{Transmission of Plant Diseases}

Sucking insects that transmit infections from diseased to healthy plants seriously affect several crop plants in Canada. Serious damage can be caused by very few infected insects. Aphids are the only vectors of barley yellow-dwarf virus of cereals, which drastically reduces grain yields. Leafhoppers transmit aster yellows, which affects not only asters but also lettuce, celery, carrots and potatoes. Aphids also transmit virus diseases of potatoes, a continuing threat to production in eastern Canada. In BC, cherries and peaches may be infested by the little cherry virus disease carried by leafhoppers (https://www.thecanadianencyclopedia.ca/en/article/insect-pests).

\section{Damage to Forest Trees and Wood Products}

Canadian forests are composed mainly of a few tree species, and these stands are normally subject to attack by insects, especially when they reach maturity. Insects (eg, spruce budworm, hemlock looper and various species of bark beetles) kill old trees to make way for regeneration. They now compete with man for forest resources. In Ontario, Québec and the Atlantic provinces, outbreaks of spruce budworm have occurred periodically for many centuries. Elm bark beetle transmits the Dutch elm disease that has decimated North American elms (https://www.thecanadianencyclopedia.ca/en/article/insect-pests).

Since 1950, pesticides have been used to prevent tree death and to maintain sustained tree-harvesting programs. Unfortunately, spraying has prolonged the outbreaks so that some parts of these forests must be sprayed yearly. Bark beetles occupy a similar position in western forests, normally attacking overaged or weakened trees. They not only compete with people for wood but also are pests in parks, where overaged stands are maintained for aesthetic reasonsm (https://www.thecanadianencyclopedia.ca/en/article/insect-pests).

The interior of lumber, poles and wooden portions of buildings may be hollowed out to form nests by black carpenter ants. In addition to serious structural damage, these large 
ants can be household pests, feeding on moist foodstuffs and sometimes damaging fabrics and paper products. Termites can cause serious structural damage to buildings. In Canada they occur in southern BC and Ontario and within more northerly cities such as Ottawa and Winnipeg (https://www.thecanadianencyclopedia.ca/en/article/insect-pests).

\section{References}

Borror, D. J., De Long, D. M. \& Triplehorn, C.A. 1981. An introduction to the study of insects. Saunders, Philadelphia. 827 pp.

Sovak, J. (1994). Insects Coloring Book. New York, United States. Dover Publications Inc. $48 \mathrm{pp}$.

Turnock ,W. J. (2012). Insects pests. Published Online.

https://www.thecanadianencyclopedia.ca/en/article/insect-pests. 